\title{
A REVISION OF HADRIAN'S PORTRAITURE
}

By

\section{VOUT $^{*}$}

\begin{abstract}
"In the second century, Roman men did not wear beards; in second-century Greece, they did. Beards were worn by the Greek poets, philosophers, and statesmen of the past. Hadrian wore a beard in life and in his portraits because he wanted to be 'the Greekling'."1
\end{abstract}

We all know what a Roman emperor looks like or rather we are familiar with imperial imagery. So were the ancients, until Hadrian rewrote the formula. The orthodoxy is that as the first bearded emperor and avid supporter of Greek culture, Hadrian changed the public face of Roman rule. Where does this conception come from? In part, it comes from the ancient literature. Although fairly scanty and most of it posthumous (with the third or fourth-century Augustan History and third-century Cassius Dio providing the fullest picture), this literature bears witness to a man who hunts, writes poetry, takes a young Greek lover, Antinous, and is initiated into the Eleusinian Mysteries; in other words, in private, who lives like a Greek. It also claims that he was curious about other cultures, especially Egyptian (into which Antinous plugs perhaps as well as into classical), and that his favourite author was the Roman epic poet, Ennius. ${ }^{2}$ But it is the Greek nature of the tradition that has captured the imagination. Or it is the novelty that a good emperor could be "so imbued in Greek studies that some called him 'Graeculus". 3 Sources of the same period see Nero and Domitian's Hellenic leanings as indicative of their tyranny. Hadrian somehow escapes similar venom to embody the success (even acme) of the Roman Empire. He is not a dilettante but an intellectual who harnesses the united power of Rome and Greece. ${ }^{4}$

This turnaround in the meaning of philhellenism should not surprise us. In some ways, trying to trace the point at which Roman attitudes towards

\footnotetext{
* A longer, revised version of this article will appear as 'What's in a beard? Rethinking Hadrian's Hellenism' in S. Goldhill and R. Osborne, Rethinking Revolutions. I would like to thank colleagues at the Impact of Empire conference for their comments on the first draft of this paper.

${ }^{1}$ D. E. E. Kleiner, Roman Sculpture (New Haven \& London 1992), 238.

${ }^{2}$ SHA, Hadrian 16.6.

${ }^{3}$ SHA, Hadrian 1.5; Aurelius Victor, Epitome de Caesaribus 14.2.

${ }^{4}$ E.g. compare G. Anderson, The Second Sophistic: a Cultural Phenomenon in the Roman Empire (London \& New York 1993), 6.
} 
the Greeks and, rather differently, Greek culture, began to shift is subsidiary to this discussion. Unlike Nero and Domitian, Hadrian died popular, or at least it was in the interests of his successors to support him. ${ }^{5}$ Roman authors show time and time again how a good emperor can be praised for the same qualities for which a bad emperor is damned. This said, however, Hadrian's philhellenism is further sanctioned by virtue of the fact that he turns it to public advantage. He devotes considerable resources into improving Greek centres such as Athens, Eleusis and Pergamum and encourages the Panhellenion or league of 'Greek' cities so as to give them greater occasion to take responsibility for themselves. ${ }^{6} \mathrm{C}$. P. Jones has recently challenged the standard line that Hadrian created the league in 131-132 C.E., preferring instead to see its foundation as a Greek initiative. ${ }^{7}$ There is evidence to argue that Hadrian's predecessors, Domitian and Trajan, invested as much (if not more) time and money into Eleusis, Cyrene and Pergamum, and that Athens is in all sorts of ways a special case. ${ }^{8}$ But none of these objections (if that is what they are) slow the increasing trend to gloss the majority of Hadrian's actions and motivations as philhellenism (positive). Whereas in the past, scholars tended to be more cautious on this issue (Eugenie Strong, for example, saying that there was "little indication that Hadrian ever wished to be classed with the Greeks or to be looked upon as leader of any Hellenic revival"), ${ }^{9}$ today almost every initiative is assigned to this heading. ${ }^{10}$ Philhellenism equates to a political stance, a successful Panhellenic programme (so much so that Griffin is now reticent about awarding Nero the adjective 'philhellenic'). ${ }^{11}$ Hadrian is credited with changing Roman imperium beyond recognition, making its fulcrum Greek culture.

\footnotetext{
${ }^{5}$ Although note Hadrian's unpopularity at SHA, Hadrian 27.1-4.

${ }^{6}$ On the Panhellenion, see A. J. S. Spawforth \& S. Walker, 'The World of the Panhellenion. I. Athens and Eleusis', Journal of Roman Studies 75 (1985), 78-104 and 'The World of the Panhellenion. II. The Dorian Cities', ibid. 76 (1986), 88-105; A. S. Benjamin, 'The Altars of Hadrian in Athens and Hadrian's Panhellenic Program', Hesperia 32 (1963) 57-86 and for a revisionist view, C. P. Jones, 'The Panhellenion', Chiron 26 (1996), 29-56.

${ }^{7}$ Jones 1996, op.cit. (n.6).

${ }^{8}$ On Eleusis, see K. Clinton, 'Hadrian's Contribution to the Renaissance of Eleusis', in S. Walker and A. Cameron, The Greek Renaissance in the Roman Empire: Papers from the Tenth British Museum Classical Colloquium (London 1989), 56-69.

${ }^{9}$ E. Strong, Art in Ancient Rome (London 1929), 110. Also J. Beaujeu, La religion romaine à l'apogée de l'empire I. La politique religieuse des Antonins (96-192) (Paris 1955), who advocates that Hadrian's eclecticism controls his philhellenism.

${ }^{10}$ Although as M. T. Boatwright, Hadrian and the City of Rome (Princeton 1987), 202 acknowledges, the existence of the Athenaeum is attested in late sources only and has never been found.

${ }^{11}$ M. T. Griffin, Nero: the End of a Dynasty (London 1984), 126.
} 
The strength of this assertion arouses suspicion. How different is Hadrian from the emperors before him (for example, Augustus is also supposed to have been initiated into the Eleusinian Mysteries) $?^{12}$ Is everything he does 'philhellenism'? Regardless of what we want to call it, might his interest in Greek cities have not been 'simple' exigency or diplomacy? Even a fleeting glance at the period in which Hadrian was ruling would suggest that the answer to this last question is confirmatory. The second century is renowned for being a time when Greek culture came together with (even assumed the lead over) Roman culture to become the most valued currency of elite interaction. Its language and heritage had a symbolic capital that outstripped the fact that relatively few of Rome's politicians were Greek. ${ }^{13}$ Seen from this angle, it matters less what Hadrian's motivations were or how different he was from Nero. The implication is that it is a different world and that Hadrian is only doing what a second-century emperor had to do. One wonders what comes first, the 'Second Sophistic', or the sources' emphasis on Hadrian's Hellenism. Or to put it another way, in order to be 'the man of the moment', did he have to be good at atticising Greek? ${ }^{14}$

It is less easy to minimise the shock of Hadrian's physical appearance as made concrete in his coinage and statuary. Here, more than anywhere, scholars have noted a radical departure from the image of emperor as established by Augustus. The fact that all of Hadrian's portraits (or at least all of those which have been identified as Hadrian) show him with a full beard and moustache, make his iconography unprecedented and the answer to what does a Roman emperor look like read differently. Recently, Cécile Evers has described it as "rompant diamétralement avec les images de ses prédécesseurs", whilst the starting and end point of Andrea Carandini's study was "una cesura profundo" between Trajan and Hadrian's reigns. ${ }^{15}$ There is no denying that a full beard appears odd next to ranks of clean-shaven prototypes. Especially when there were question marks over Hadrian's adoption by Trajan, one might have expected him to use the power of resemblance to strengthen his right to rule. It

\footnotetext{
${ }^{12}$ See Dio Cassius 51.4.1 and D. Kienast, 'Hadrian, Augustus und die eleusinischen Mysterien', Jahrbuch für Numismatik und Geldgeschichte 10 (1959-60), 61-69. Others to have been initiated include Cicero (De Legibus 2.14.35) and Sulla (Plutarch, Sulla 26.1). Also of interest here is Trajan's honouring of philosophers and encouragement of the liberal arts, Pliny, Panegyricus 47.1-2.

${ }^{13}$ G. W. M. Harrison, The Romans and Crete (Amsterdam 1993), 226.

${ }^{14}$ SHA, Hadrian 16.5-6.

${ }^{15}$ C. Evers, 'Les portraits d'Hadrien: "varius, multiplex, multiformis"', in J. Charles-Gaffiot \& H. Lavagne, Hadrien: trésors d'une villa impériale (Milan 1999), 13 = 'I ritratti di Adriano: "varius, multiplex, multiformis"', in Adriano: archittetura e progetto (Milan 2000), 21; A. Carandini, Vibia Sabina. Funzione politica, iconografia e il problema del classicismo adrianeo (Rome 1969), 21.
} 
also seems as though the presence of a beard was seen as odd or at least in need of explanation in antiquity. For why else would the Augustan History have felt it necessary to mention that Hadrian had grown it to cover his scars? ${ }^{16}$ Again the modern solution is philhellenism. From Diana Kleiner's statement at the start of this paper to the words of Elena Calandra, Hadrian's beard was not a personal but strategic decision, "per emulare e quasi revivere già nell'aspetto gli intellettuali e i politici della Grecia classica". ${ }^{17}$ More specific than this has been the suggestion that the beard is that of a Greek philosopher. ${ }^{18}$ One of the main proponents of this analysis, Paul Zanker, is cleverer in his formulation arguing that, whilst admittedly not the long beard of the philosopher, it must still be seen as a "cultivated beard". 19

What follows uses Hadrian's beard as a way of rethinking the 'hot potato' of his Hellenism. It examines Hadrian's portraiture and that of other emperors to exemplify the extent to which Hellenism, or the intellectual credence we now give to Hellenism, is skewing, even obscuring our view. Did the wearing of a beard in the second century imply a Greek identity, and if so, why philosophical? Might some of Hadrian's subjects not have nattered about his scarring rather than exalting his beard as a subtle nod to Greece? These questions, though specific in their application, impact on the representation of Hadrian more broadly. How Greek was his imagery or how much more Greek than that of his predecessors? It should be acknowledged that there is nothing in the extant literature to suggest that Hadrian's visual material (his beard, portraiture or architecture) was especially Greek in conception. Pausanias describes Hadrian as benefactor of Greek and barbarian cities. ${ }^{20}$ The writers of the Augustan History and Cassius Dio, meanwhile, mention harbours, water supplies and aqueducts. ${ }^{21}$ There is little innovation here, only 'long, straight roads'. We might also wonder how far the reputation of Hadrian's predecessor, Trajan, as a vir militaris comes up against Hadrian's as 'philhellene' to discourage any search for continuity. It would be worth remembering at this point that it is Trajan and not Hadrian who in Julian's third-century Caesars is credited with the 'Greek vice' of loving boys! ${ }^{22}$

\footnotetext{
${ }^{16}$ SHA, Hadrian 26.1.

${ }^{17}$ E. Calandra, Oltre la Grecia: alle origini del filellenismo di Adriano (Naples 1996), 173. Also H. G. Niemeyer, 'Hadrians Bart', Hefte des Archäologischen Seminars der Universität Bern (1983), 39-43.

18 A. Hekler, Greek and Roman Portraits (London 1912), xxxvi and 'Philosophen und Gelehrtenbildnisse der mittleren Kaiserzeit', Die Antike 16 (1940), 115-141.

${ }^{19}$ P. Zanker, The Mask of Socrates. Translated by A. Shapiro (Berkeley 1995), 218.

${ }^{20}$ Pausanias 1.5.5.

${ }^{21}$ SHA, Hadrian 19.2; 20.5-6 and Dio Cassius 69.5.3.

${ }^{22}$ Julian, Convivium 311. See also Dio Cassius 68.10.2 and SHA, Hadrian 2.7.
} 


\section{The beard as a symbol of Greekness}

Hadrian's beard is Greek. "Hadrian is more Greek than Roman". ${ }^{24}$ Let us accept these formulations for a moment to pursue their implications and examine the evidence on which they are based. The clearest support comes from a statue now in the British Museum in London (Plates VII, fig. 1) ${ }^{25}$ It combines Hadrian's bearded head with a torso that spurns the toga (traditional signifier of Romanitas) for the chiton and himation of a Greek citizen. ${ }^{26}$ The pose, with the right hand tucked into the himation, allows for a more precise interpretation. It is associated with Greek intellectuals (a statue-type that originated in the late classical period but was not uncommon under the empire). Beards are similarly seen as symbols of a classical education: "if you think to grow a beard is to acquire wisdom, a goat with a true beard is at once a complete Plato", scoffs a poet preserved in the Palatine Anthology. ${ }^{27}$ The obvious conclusion to reach in this context is that the beard and body spark off each other to cloak Hadrian as a philosopher king. This is made more convincing once it is recognised that the only other emperor to appear (or survive and be identified) in this costume is Julian, the empire's second most notable 'philhellene' ${ }^{28}$ Literary sources 'prove' that Hadrian favoured a Greek cloak (pallium) in public and private, morning, noon and night. ${ }^{29}$

Unusually for an ancient statue, the original context of this portrait is recoverable. At two-metres tall it stood in the Temple of Apollo at Cyrene in North Africa. It was discovered together with several similar intellectual

\footnotetext{
${ }^{23}$ See e.g. W. L. MacDonald \& J. A. Pinto, Hadrian's Villa and its Legacy (New Haven \& London 1995), 5; S. Goldhill, Being Greek Under Rome: Cultural Identity, the Second Sophistic and the Development of Empire (Cambridge 2001), 11.

${ }^{24} \mathrm{R}$. Syme, 'Hadrian the Intellectual' in Les empereurs romains d'Espagne (Paris 1965), 247. See also R. Syme, 'Hadrian as Philhellene. Neglected Aspects', Bonner Historia-Augusta-Colloquium 1982/3 (1985), 341-362.

${ }^{25}$ British Museum no. 1381. inv. no. 1861.11.27.23. See J. J. Bernoulli, Römische Ikonographie 2.2 (Stuttgart 1891), 109, no. 15; E. Rosenbaum, A Catalogue of Cyrenaican Portrait Sculpture (London 1960), 51, cat. no. 34, pls. 26.1-2 and 27.1; J. Huskinson, Roman Sculpture from Cyrenaica in the British Museum (London 1975), 38-39, cat. no. 69, pl. 28; C. Evers, Les portraits d'Hadrien: typologie et ateliers (Brussels 1994), 125-126, cat. no. 57; J. Huskinson, Experiencing Rome: Culture, Identity and Power (London 2000), 9, fig. 1.4.

${ }^{26} \mathrm{C}$. Vout, 'The Myth of the Toga: Understanding the History of Roman Dress', Greece and Rome 43.2 (1996), 204-220.

${ }^{27}$ Anthologia Palatina 11.430.

${ }^{28}$ Inv. no. MR 246, Louvre, Paris: see K. de Kersauson, Catalogue des portraits romains. Musée $d u$ Louvre (Paris 1996), no. 251. On his Hellenism, see P. Athanassiadi-Fowden, Julian and Hellenism: an Intellectual Biography (Oxford 1981).

${ }^{29}$ See Zanker 1995, op.cit. (n. 19), 218.
} 
types suggesting that it was part of a series. It is the only one of the 150 surviving sculpted portraits of Hadrian and all extant coin portraits to show him wearing Greek clothes. Zanker claims that "Cyrene was surely not the only city that paid homage to him in this style", and he might be right. ${ }^{30}$ Only a tiny fraction of the 150 sculptures still have bodies (we shall be coming back to these presently). Any of the heads might have originally have been palliati, as might the statues which once graced the bases attested in Benjamin's study of the east. ${ }^{31}$ But it is impossible to deny that the evidence as it stands contravenes the current orthodoxy. It is dangerous not to concede the possibility that Cyrene might be a special case. As soon as we do this, we realise that there are important reasons why Cyrene might have been different. It was one of the few cities beyond Greece to have been part of the Panhellenion and as such, might have set more store than most on its (and its emperor's) share of Greek heritage. It had a special relationship with Hadrian who re-founded it after the Jewish revolt of 115 C.E. Letters were displayed in the centre to show that he too stressed the city's Greek roots. ${ }^{32}$ All of this suggests that whatever everyone else was doing, Cyrene was making sense of Hadrian in its own terms, and had personal grounds for its statue's Greek appearance. Elsewhere in North Africa, Hadrian was packaged as a pharaoh. ${ }^{33}$ Perhaps Cyrene is similarly inventive, only less (to post-Renaissance eyes) extreme.

It is valuable here to come back to the contention that Hadrian favoured Greek clothing in public and private. The sources cited to support this are the Augustan History and Cassius Dio. They report that he dressed in Greek style at imperial banquets and when he was agonothetes at the Dionysia in Athens. Already this is more precise in its frame of reference than is suggested by secondary authors. But it is further qualified by its context. Cassius Dio claims that Hadrian "carried off his local costume splendidly at the festival", ${ }^{34}$ hardly a statement that implies he wore it

\footnotetext{
${ }^{30}$ Zanker 1995, op.cit. (n. 19), 218.

${ }^{31}$ Benjamin 1963, op.cit. (n.6). The same has to be conceded of the various statues of Hadrian dedicated by cities of the Greek world in the Olympeion in Athens (Pausanias, 1.18.6).

${ }^{32}$ See P. M. Fraser, 'Hadrian and Cyrene', Journal of Roman Studies 40 (1950), 77-90; Spawforth \& Walker 1986, op.cit. (n.6), 96 and M. T. Boatwright, Hadrian and the Cities of the Roman Empire (Princeton 2000), 173-184.

${ }^{33}$ No sculpture in the round survives, or at least that can be identified with certainty. But for temple reliefs on the Sanctuary of Hathor at Dendera, at Philae and at Deir el - Shelwit, see F. Daumas, Le Temple de Dandara (Cairo 1959), 95 A-B and Z. Kiss, Etudes sur le portrait imperial romain en Egypte (Warsaw 1984) 153, fig. 113.

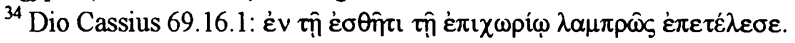


regularly, whilst the Augustan History does not say he always wore the pallium but the pallium or toga when he was at dinner. ${ }^{35}$ Neither claim should lead us to expect ranks of similar statues. If anything, it would appear that the pallium is being used to make the emperor blend into a particular setting. This refinement of our reading should be combined with a caution about the integrity of the statue from Cyrene. Not only was the head found separate from the body, but is made from a finer, whiter marble. The assumption is that they were put together in antiquity, but this raises questions about why the body (ease or efficacy) was reused. Doubts were also once raised about the identity of the portrait (as indeed they were about the pallium-clad statues of 'Julian'). ${ }^{36}$ If we accept that it is Hadrian, the notion that he did not wear a pallium all the time but only when he had to fuels further revision of the statue's status. Rather than the epitome of philhellenism, it becomes an example of imperial adaptability: not an obsession with Greek culture but a case of "when in Rome....". 37

Often we see what we want to see. As far as Hadrian's beard is concerned, most label it a philosopher's beard, a quotation lifted from Greek statuary and (as the Greek Anthology has already highlighted) from everyday association as filtered through the literature. ${ }^{38}$ This explanation works better for the statue from Cyrene than it does for other statues of Hadrian. But even at Cyrene, the neatness of the formulation overlooks the import of ill-fitting details. As Tom Mathews says when faced with the image of the so-called philosopher-Christ,

"his garb of long tunic, with his arm caught in the sling of his pallium, identifies him as a philosopher, and indeed this is how the early Christian apologists from Justin to Augustine regarded him. But the philosopher's role leaves other aspects of the image unexplained." 39

\footnotetext{
${ }^{35}$ SHA, Hadrian 22.4-5.

${ }^{36}$ Bernoulli 1891, op.cit. (n.25), 109, cat. no. 15. For doubts about the statue of Julian, see J. J. Bernoulli, Römische Ikonographie 2.3 (Stuttgart 1894), 243 and E. Michon, Catalogue sommaire des marbres antiques (Paris 1922), 57.

${ }^{37}$ So Scipio Africanus is said to have worn it in Sicily where Latin and Greek culture co-existed (Livy 29.19.12), Rabirius in Alexandria (Cicero, Pro Rabirio Postumo 9.29) and Tiberius in Rhodes (Suetonius, Tiberius 13.1).

${ }^{38}$ See also Persius 4.1; Horatius, Satirae 1.3.33 and Juvenalis 14.12.

${ }^{39}$ T. F. Mathews, The Clash of Gods: a Reinterpretation of Early Christian Art (Princeton 1993), 39.
} 
The main points of conflict in Hadrian's statue are the style of his hair and beard and overall perkiness. The comparison between Plato and goat might already give it away that a philosopher's beard is, ideally at least, unkempt and straggly. Classical statues of philosophers and 'copies' from throughout the Roman period (contemporary and subsequent to Hadrian) typically have long, lank hair that is sometimes thinning on top. These factors fit an overall formula that perceives wisdom and age as synonymous. Philosophers look old. They have sunken cheeks, saggy chests and wasted arms. ${ }^{40}$ Often they are depicted seated with a scroll in their hand (whereas Hadrian from Cyrene holds a laurel branch, plant of Apollo in whose sanctuary he stands) ${ }^{41}$ In their purest fourth-century form, they are so hardened as not to wear a tunic beneath their cloak so as to put more of their age and wisdom on display. ${ }^{42}$

Hadrian's coiffure, cropped beard and youthful features set him at an uncomfortable distance from the stereotype. Conversely, one of the closest matches is second-century millionaire and sophist, Herodes Atticus, whose slim, shrunken head and long beard survives in sculptures from his private estates and public settings throughout the Greek mainland. Susan Walker goes as far as to claim that there is, "nothing Roman about Herodes' portrait, which may be explained as a local Greek development so archaising in appearance that it has been confused with late classical funerary art." ${ }^{.43}$ She over-stresses the oddity of his appearance (or rather underestimates the number of busts currently identified as Aristotle of Plato which are really those of second-century intellectuals), but must be right to put it in a different category from that of Hadrian. Traditionally, the presence of a beard in both of them (regardless of the differences) has meant that Hadrian has been seen as the initiator and Herodes following the fashions at court. ${ }^{44}$ But if Hadrian's beard is not that of a philosopher, then what are we to make of it? Smith in an article on the fourth and fifth-century 'philosopher portraits' from Aphrodisias lends credence to this question by arguing that the short, neatly trimmed beard of one of his subjects dissociates him from

\footnotetext{
${ }^{40}$ On the appearance of philosophers, R. R. R. Smith, 'Late Philosopher Portraits from Aphrodisias', Joumal of Roman Studies 80 (1990), 144-146 and 'Kings and Philosophers', in A. Bulloch, E. S. Gruen, A. A. Long \& A. Stewart, Images and Ideologies: Self-Definition in the Hellenistic World (Berkeley \& Los Angeles 1993), 202-212.

${ }^{41}$ See M. Bieber, Ancient Copies: Contributions to the History of Greek and Roman Art (New York 1977), 138 and 'Romani Palliati', Proceedings of the Philological Society 103 (1959), 374-417.

${ }^{42}$ Compare the rhetoric about 'real' Romans not wearing a tunic beneath their toga, Aulus Gellius 6.12.3-4.

${ }^{43} \mathrm{~S}$. Walker, 'Bearded Men', Joumal of the History of Collections 3 (1991), 268.

${ }^{44}$ See K. Schefold, Die Bildnisse der antiken Dichter, Redner und Denker (Basel 1997), 332-333.
} 
the ideal philosopher type and makes him more of a 'real person'. Are there other possible sources that Hadrian is mining? Or, as Smith prefers for his example, was his beard 'simply' a "fashion statement" rather than a deliberate quotation from the past? ? $^{45}$

Susan Walker has recently refined her answer to this question to describe Hadrian's beard as "worn in the style of Pericles". ${ }^{46}$ Pericles' short curly beard and moustache put her on safer ground than those who have favoured philosophers. It is an identity that would complement Hadrian's interest in Athens, especially his enthusiasm to build. But the more one pursues the implications of this hypothesis, the more one is made to doubt it. If one reads Plutarch so as to get a sense of Pericles' reputation under Hadrian, one encounters an icon whose head is too long (hence the helmet) and whose overall appearance is reminiscent of the tyrant Pisistratus (although this is hardly surprising as he too was a prolific builder, inaugurator of the Temple of Olympian Zeus in Athens which Hadrian was to finish) ${ }^{47}$ These are hardly auspicious parallels. To make matters worse, there is little evidence to suggest that Hadrian or his biographers were conscious of such a connection, or at least not compared to the stronger associations with a bearded Jupiter or Zeus. ${ }^{48}$ There are other candidates: Aeschines, for example, who has perhaps the best iconographic and biographic credentials (short beard, soldier, scribe, actor) or Alcibiades, who is sexy, wealthy, honoured by Hadrian, but highly controversial (his colourful character aside, there is considerable uncertainty over whether the portrait with its short beard and moustache which exists in a number of 'copies' is actually him). ${ }^{49}$ In every case, there are problems. On the most basic level, how strong do similarities in the style of beard and hair and face

\footnotetext{
${ }^{45}$ Smith 1990, op.cit. (n.40), 150.

${ }^{46}$ S. Walker, Greek and Roman Portraits (London 1995), 91.

${ }^{47}$ Plutarch, Pericles 7.1.

${ }^{48}$ A. R. Birley, Hadrian the Restless Emperor (London 1997), 218-219 as well as in his introduction and epilogue propagates this notion of Hadrian as Pericles but his enthusiasm appears to stem more from the suitability of the parallel than concrete evidence of its existence in antiquity. For Hadrian honoured as Zeus/Jupiter, see ibid, passim; A. Raubitschek, 'Hadrian as Son of Zeus Eleutherios', American Journal of Archaeology 49 (1945), 128-133; W. E. Metcalf, 'Hadrian, Jovis Olympius', Mnemosyne 27 (1974), 59-66.

${ }^{49}$ The study of Aeschines' portraiture is founded upon two herms inscribed with his name (Salle delle Muse, Vatican, inv. 297 and British Museum, inv. no. 1839); see G. Richter, The Portraits of the Greeks 2 (1965), 212, figs. 1372-1375 and 1378-1379. On Alcibiades' honours by Hadrian, see Athenaeus, Deipnosophistae 13.574 and on the doubts over the identity of the Copenhagen series (as represented by I. N. 2263, Ny Carlsberg Glyptothek, Copenhagen), see G. Richter, The Portraits of the Greeks 1 (1965), 105, figs. 449-450.
} 
have to be for them to be called 'inspirational'? Can a beard alone quote a visual model, if the subject's hairstyle and face shape are different? One cannot help be sceptical. The claim that Hadrian's beard evokes a person rather than a type increases the potential for, and the number of questions raised by, discrepancy.

Put the head of Hadrian from Cyrene on another kind of body and it signifies very differently. The beard on his togate statue from Rome is less obviously sophistic than that at Cyrene, on his statue from Frosinone, where he has a naked body in the style of the Ares Borghese, more convincingly part of his visual armoury as Mars. ${ }^{50}$ Both of these are unique in the corpus of Hadrian's statuary. One could claim that Rome "was surely not the only city that paid homage to him in this style". But as with Zanker and Cyrene, we cannot know. Instead, we ought to examine other extant bodies. Is there a preferred type? And if so, does it strengthen or deny the power of Hadrian's Greekness? Might it present an adequate explanation for his wearing of a beard? Four of the surviving statues are nude in the style of Diomedes in flight, the original of which is traditionally attributed to fifth-century Greek sculptor Kresilas. The Homeric hero is shown having stolen the Palladion, which he holds in his left hand. ${ }^{51}$ Luckily, their find spots are recoverable: two originate in modern Turkey, another near Sousse in Tunisia, and the last, and most surprising perhaps, in a theatre in Vaison in Gaul (Pl. VII, fig. 2) ${ }^{52}$ Its existence broadens the application of any argument. The first two are usually dated to 121 C.E. when Hadrian visited the region. ${ }^{53}$ The last two are more complicated but have portraits of a type dated to 128 C.E. ${ }^{54}$ Between them, they cover a large span (temporally and geographically) of Hadrian's reign.

\footnotetext{
${ }^{50}$ For the togate statue (Capitoline Museum, Rome, atrio 5, inv. no. 54), see Evers 1994, op.cit. (n.25), 158-159, cat. no. 99 and for Hadrian as Mars (Capitoline Museum, Rome, salone 13, inv. no. b34), Evers, ibid, 159-160, cat. no. 100.

${ }^{51}$ On the original, see A. Stewart, Greek Sculpture: an Exploration (New Haven \& London 1990), 168 and for this and Roman adaptations, J.-M. Moret, Les pierres gravées antiques représentant le rapt $d u$ Palladion (Mainz 1997). For statues of Hadrian and Diomedes, see E. Calandra, 'Ancora su Adriano: archetipi scultorei e programmi iconografici', in R. F. Docter \& E. M. Moorman, Proceedings of the $15^{\text {th }}$ International Congress of Classical Archaeology, July $12-171998$ (Amsterdam 1999), 100-102.

${ }^{52}$ For the Perge statue (Antalya, mus. inv. A3861 and A3863), see Evers 1994, op.cit. (n. 25), 83, cat. no. 7; Pergamum (mus. inv. no. 160), Evers, ibid. 150, cat. no. 88; Sousse (Archaeological Museum), Evers, ibid, 183, cat. no. 133 and Vaison-la-Romaine (Musée municipal), Evers, ibid, 190, cat. no. 144.

${ }^{53}$ See Evers, 1994, op.cit. (n.25), 82-83 and 150. Although the base of the Pergamum statue acclaims Hadrian as a god, there is nothing about the base or inscription to dictate that it had to have been posthumous.

${ }^{54}$ The portraits of Hadrian are divided into 7 types. The separation of sculptures into each of these types is more difficult than most art-historians acknowledge, especially in the case of Hadrian where they do see iconographic overlap or Klitterungen between the types. Does a sculpture have to have
} 
The Hellenic heritage of these images is obvious. But is there anything that might explain Diomedes in particular? He is a key figure in the history of the Palladion, an important emblem of Rome's origins and continued domination, so important, it seems, that Hadrian exploits it elsewhere in his statuary and Constantine buries it together with Christian relics at the base of his column in 'New Rome'. We shall return to this example of Hadrian's statuary at the end of this paper. It would seem that such a symbol of continuity was particularly crucial for emperors who tried to change the imperial formula more than most. More specifically, like the literary Hadrian, Diomedes is closely associated with horses and, according to Strabo, is said to have founded many cities, given his name to islands and been worshipped as a god. ${ }^{55}$ One can immediately see the suitability of Diomedes as a paradigm. But how extensive was this association? Is his prominence an accident of survival? Is it not the case that one could find similarities between Hadrian and several ancient figures (especially Alexander) if one trawled the literary sources long enough? ${ }^{56}$ What these objections underplay is the possible significance that Diomedes is bearded. In the version attributed to Kresilas, the beard is short, curly and tapers towards the chin not unlike that of Hadrian. Even without a moustache, it could be argued that this facial hair fits as well as that of a philosopher. This is without the support that Diomedes is represented with fuller beard and moustache on cameos and southern Italian pots. ${ }^{57}$

But we must not allow this 'coincidence' to cloud our judgement nor make a rule out of four examples. The motivating factor, and basic error, is that we still seek to explain the beard as Greek, and not just Greek but a definition of Greek that suits the 'Second Sophistic'. By this I mean that Hadrian has to be an intellectual or imitate a hero from Greek history, embody Culture with a capital $\mathrm{C}$. We might be on safer ground with the more general statement that to have a beard was to follow Greek fashion (whether Diomedes or Riace Bronze B). Or rather that for Hadrian to encourage the cult of his male lover, Antinous, he had to have a beard so as

been made at the same time as others of its type? It is, therefore, with immense caution that either example can be dated. Both are the Imperatori 32 type, which $\mathrm{W}$. Wegner, Das römische Herrscherbild II 3. Hadrian Plotina Marciana Matidia Sabina (Berlin 1956) proposed was created for Hadrian's Pater Patriae title in 127-128 CE.

${ }^{55}$ Strabo 6.3.9.

${ }^{56}$ See e.g. Hadrian and Alexander's love of hunting, and their excessive mourning for both their horses and male companions. Compare Arrian, Anabasis 7.14.3-4 and SHA, Hadrian 14.5-6.

${ }^{57}$ Moret 1997, op.cit (n.51), plate 118. 
to be understood as the erastes and create the need for his eromenos' role. ${ }^{58}$ But even if there is an element of truth in the above, its efficacy relies on the 'fact' that beards were not Roman, or at least that a second-century Roman was so surprised by Hadrian's beard as to have endeavoured to make sense of it (and in terms familiar from Greek culture). In Rome before Hadrian, "the beard had been worn after 300 B.C. only as a sign of mourning", says Eugenie Strong. ${ }^{59}$ Beards were worn by young adults and then ritually removed and dedicated to the gods at the age of twenty-four. ${ }^{60}$

Scan the literary sources and this is the impression we get. Juvenal and Plautus typecast Greeks as barbati or palliati. ${ }^{61}$ Dio and Suetonius celebrate the removal of several young emperors' beards. This material is cause and comfort for seeing Hadrian's beard as departure. But one set of evidence is stereotypical, the other normative. Neither may bear much relation to what Greeks and Romans did or saw in the street. Put the emphasis on continuity rather than change and watch it pale into perspective. The final section of this paper briefly demonstrates how an emphasis on Hadrian's difference has led to an oversight of potential models within Rome's own imperial tradition. For all Diomedes' Greekness, his body-type had already had an impact on sculptures from Trajan to Gaius Caesar or Augustus. $^{62}$ Their existence should make us reconsider what we make of Hadrian's association (how far were Hadrian or his artists seeing the suitability of Diomedes and how far 'merely' making him look like an emperor, doing what artists had always done?). But it is not just the iconography of the body that was exploited: we shall soon see that the hesitation over whether the second is Augustus or Gaius stems in part from the presence of a beard.

\section{The beard as a Roman reality}

Hadrian was the first bearded emperor. This statement relies on us disregarding or explaining away important Roman evidence. It chooses not to stress that 'Graeculus' can be a negative term and that a bearded Hadrian might not have been recognised or accepted (whatever the period) if

\footnotetext{
${ }^{58}$ For the most recent catalogue of statues of Antinous, see H. Meyer, Antinoos: Die archäologischen Denkmäler unter Einbeziehung des numismatischen und epigraphischen Materials sowie der literarischen Nachrichten (Munich 1991).

${ }^{59}$ Strong 1929, op.cit. (n.9), 106.

${ }^{60}$ Walker 1991, op.cit. (n.43) and also W. S. Anderson, 'Juvenal: Evidence on the Years AD 117128', Classical Philology 50 (1955), 255.

${ }^{61}$ Juvenalis, Satirae 14.10-14and 215-218; Plautus, Curculio 288.
} 
iconoclastic and radically Greek. Zanker, for example, claims that on Trajan's column beards are avoided. ${ }^{63}$ This is not true. Several Roman officers on the column and Arch of Trajan at Beneventum have a similar short beard and moustache to Hadrian (so similar that he has been identified on both monuments) ${ }^{64}$ Once this evidence is admitted, might some of the bearded statues assumed to follow in his footsteps not have been made before him? Might he not, far from following Greek tradition, have been following the fashion in Rome? But even if a case could be made, there is still the contention that he is flouting imperial tradition in being a barbatus Caesar. Augustus had established the pattern for what a Roman emperor looks like. Hadrian breaks the mould. But this is to deny that earlier emperors had been represented bearded at least on their coinage. Most extensive in this were Nero and Domitian, although their efforts could be bracketed as proto-attempts at displaying their Greek affinities (a parenthesis which would work for rather than against Hadrian's beard as a marker of his Hellenism). ${ }^{65}$ But Augustus and Titus are also shown bearded. ${ }^{66}$ Their existence might mean that for an ancient viewer, the image of a bearded emperor was not (on coins at least) something new.

As far as the coins are concerned, Augustus' light beard (which usually runs from the temples to the chin but in some issues also covers the upper lip) is confined to those between 42 and 37 B.C.E. before he became Augustus, and is sometimes accompanied by the legend Divi Iulii Filius. His youth alone would account for its presence. But it turns out that these coins continue to be issued after the date of the depositio barbae recorded by Cassius Dio. ${ }^{67}$ Otto Brendel explains this inconsistency as a need to show mourning for Julius Caesar (whose name is sometimes mentioned), Walker as a "sign of vengeance for the murder of his adoptive father" ${ }^{68}$ In both cases, any wider-reaching significance is explained away. By the same token, for a bearded statue to be accepted as Augustus, it has to be an early example. So Brendel classifies his 'type B' portrait as 'mourning' even though the beard is not unkempt (as one would expect of someone too upset to shave) and Fittschen and Zanker argue that despite its lock scheme, this type is more

\footnotetext{
${ }^{62}$ See Moret 1997, op.cit. (n.51), 208.

${ }^{63}$ Zanker 1995, op.cit. (n.19), 218.

${ }^{64}$ See Walker 1991, op.cit. (n.43), 271.

${ }^{65}$ For Domitian's beard, see e.g. BMC II Titus 230-248 and Domitian 1-58.

${ }^{66}$ For Titus' beard, see e.g. BMC II Vespasian 707-711 and Titus 150-217.

${ }^{67}$ Dio Cassius 48.34.3.

${ }^{68}$ Walker 1991, op.cit. (n.43), 271.
} 
likely one of Augustus' heirs (probably Gaius). ${ }^{69}$ One tentatively wonders whether bearded Octavians (an Augustus bearded like Philip of Macedon) might emerge, if we were not so keen to stress his modesty.

Like Augustus, the literature makes much of the dedication of Nero's beard in 59 C.E. and his smooth transition to manhood. ${ }^{70}$ Again the coins that show him bearded are issued after this event (in the case of aurei, from 64 to 68 C.E., and dupondii, from 64 to 66 C.E.) and are assumed by Hiesinger to be linked to the Decennalia. ${ }^{71}$ Given the number of coins and significance of such a landmark, there may well have been hundreds of bearded statues. Act upon act of damnatio memoriae strengthens the probability that (as with Domitian) these do not survive. ${ }^{72}$ Acknowledging this prospect makes it difficult to believe that archaeologists like Kleiner ignore this material, especially since others have argued, as Evers did with Hadrian, that "Neron rompt avec la tradition de l'ancien principat". ${ }^{73}$ Nero's podgier features, thicker hair and preference for the radiate crown do set him apart him from other Julio-Claudians who are often hard to differentiate. Why is this? Predictably perhaps in line with his reputation as a tyrant these features tend to be glossed as a return to the visual vocabulary of Hellenistic kingship. More recently, Miriam Griffin has isolated Nero's beard as specifically recalling his family (Aheno-barbus) and has likened his coins to those of his great-grandfather who put a bearded ancestor on the reverse. ${ }^{74}$ But she is not comparing like with like: there is no escaping that Nero himself is bearded (and crucially why then in his reign?). His reputation permitting (and acceding that his imagery may have worked well during his lifetime, especially in the east with its 'false Neros'), ${ }^{75}$ might Hadrian not have been exploiting an established symbol of Roman potency? As far back as 196 B.C.E., coins showing the consul Flamininus with a beard were issued to honour his involvement with Greece. ${ }^{76}$

\footnotetext{
${ }^{69}$ O. Brendel, Ikonographie des Kaisers Augustus (Nurnberg 1931), 38 and K. Fittschen \& P. Zanker, Katalog der römischen Porträts in den Capitolinischen Museen und den anderen kommunalen Sammlungen der Stadt Rom (Mainz 1985), 21-25, cat. no. 20.

${ }^{70}$ Suetonius, Nero 12.

${ }^{71}$ U. W. Hiesinger, 'The Portraits of Nero', American Journal of Archaeology 79 (1975), 124.

${ }^{72}$ Hiesinger 1975, op.cit. (n.71), 120 disqualifies a bearded head of green granite, now in Haifa Museum of Ancient Art (inv. 2031).

${ }^{73}$ H. P. L'Orange, Apotheosis in Ancient Portraiture (Oslo 1942), 264.

${ }^{74}$ Griffin 1984, op.cit. (n.11), 22, n. 17.

${ }^{75}$ Dio Cassius 63.9.3; 64.19.3.

${ }^{76}$ See Walker 1991, op.cit. (n. 43), 271.
} 
The most common surviving statue of the emperor Hadrian turns out to be the cuirassed type, the most aggressive of which from Hierapytna in Crete, shows him stamping on a barbarian (Pl. VII, fig. 3) ${ }^{77}$ There are currently fourteen of these statues catalogued. ${ }^{78}$ Not all survive with their heads intact (some are identified by the Palladion and she-wolf on their cuirass, imagery exclusive to Hadrian). But those that do have heads have crueller expressions than Hadrian's other portraits. This and their emphasis on Roman conquest lead one to expect that they were displayed close to the frontiers (to warn against potential revolts) or the west of the empire (where, unaccustomed to ruler worship and the shared import of Greco-Roman heritage, images of power might have had to be more obvious and intimidatory). Incredibly, when one considers our current perception of Hadrian and his century, as well as what the literary sources say about his disdain for Trajan's expansionist policies, all were found in the east. ${ }^{79}$

There are a further three statues from Crete plus one from Cyrene, making a total of four for the province. Perhaps the success of Trajan in the Jewish Revolt helps to explain these. ${ }^{80}$ We have already seen Hadrian exploiting this military victory: perhaps in Crete and Cyrene this is what imperial intervention meant to them. This is another 'nail in the coffin' of their Hadrian as philosopher. Further battering comes from the fact that four of these cuirassed statues are from Athens, centre of Hadrian's so-called Panhellenic programme, one from Syria, one from Antalya in Turkey, and the other from Olympia, where one might have imagined him as a hero or Greek god as at Pergamum. A saving grace might be that they date to early in his reign when it was crucial for him to appear invincible like Trajan. The inscription on the base of the Antalya example locates it in $121 \mathrm{C} . \mathrm{E}^{81}$ But that from Olympia is more problematic. Its find spot in the nymphaeum of

\footnotetext{
${ }^{77}$ Found in the theatre and now in the Archaeological Museum in Istanbul (Inv. no. 50): see Evers 1994, op.cit. (n.25), 119, cat. no. 50; H. G. Niemeyer, Studien zur statuarischen Darstellungen der römischen Kaiser (Berlin 1968), 97, cat. no. 53; Kleiner 1992, op.cit. (n.1), 242, fig. 205; and N. Hannestad, Roman Art and Imperial Policy (Højberg 1986), 200, who is so convinced by Hadrian's reputation as to conclude that he cannot have approved of such a statue.

${ }^{78}$ Calandra 1999, op.cit. (n.51), 101.

${ }^{79}$ For current orthodoxy on this issue, see N. H. Ramage \& A. Ramage, Roman Art: Romulus to Constantine (London 2000), 209. See also J. Toynbee, The Hadrianic School: a Chapter in the History of Greek Art (Cambridge 1934), 5, who dismisses Hadrian's exercitus coins as being of "no specific artistic interest".

${ }^{80}$ Although note that M. Goodman, Jews in the Graeco-Roman World (Oxford 1998), 7 claims that because the Bar Kokhba revolt was "out of tune with the spirit of Hadrian's reign" it was far less emphasised than under Trajan.
}

${ }^{81}$ See Evers 1994, op.cit. (n.25), 84. 
Herodes Atticus gives it a date of 149-153 C.E. It is interesting that it is as a military man that Hadrian is remembered, especially in such a context, where (more than most places) one would have expected him as a sophist. ${ }^{82}$

Concentrate on the breastplate, of course, with its unification of shewolf and palladion, and one can still call these statues evidence of Hadrian's "predilection for the culture, art and traditions of ancient Greece", or on the body, and one still sees the contours of Diomedes. ${ }^{83}$ But one feels one is forcing the issue. Indeed it is hard to deny that these statues bridge the "cessura profondo" between Trajan and Hadrian's reigns and reputations, and that the overall effect is not one of subtlety or Hellenism but of straightforward Roman aggression. ${ }^{84}$ Hadrian's cultivated beard becomes tyrannical like Nero's beard, or the mark of a Roman bruiser as on Trajan's column. I am not saying that this is how we should see Hadrian, rather be aware of the other side of the story. His beard marks him out as different from Trajan, who as Optimus Princeps in some ways already stood as the apogee of the existing system. But is it necessarily more loaded than Caligula's jug-like ears or Nero's podgier face? 'Hadrian the philhellene' has become as common and potentially misleading a tag as 'Caligula the mad' or 'Nero the monster' and blocks just as many avenues. A quarter of a century ago and it was the cuirassed statues that were hailed as "die reichste Überlieferung des hadrianischen Bildprogrammes". ${ }^{85}$ Today we would do well to examine our application of Hellenism and the effect it is having on how we view Hadrian's imagery.

Nottingham, December 2002

\footnotetext{
${ }^{82}$ Evers 1994, op.cit. (n.25), 139-140 and R. Bol, Das Statuenprogramm des Herodes-AtticusNymphäums (Berlin 1984). Attention might also be drawn here to the fact that the posthumous image of Hadrian on the Altar of Ephesus (if it is Hadrian) is togate.

${ }^{83}$ For the she-wolf and Palladion, see I. M. Ferris, Enemies of Rome: Barbarians Through Roman Eyes (Stroud 2000), 82 and C. Dulière, Lupa Romana: recherces d'iconographie et essai d'interprétation (Brussels 1979), $198 \mathrm{ff}$.

${ }^{84}$ On the Roman (as opposed to Greek nature) of the cuirassed statue, see Calandra 1999, op.cit. (n.51), 102.

${ }^{85} \mathrm{~K}$. Stemmer, Untersuchungen zur Typologie, Chronologie und Ikonographie der Panzerstatuen (Berlin 1977), 32.
} 